\title{
THE EFFECTS OF N-METHYL-D-ASPARTATE RECEPTOR BLOCKADE ON OXIDATIVE STATUS IN HEART DURING CONDITIONING MANEUVERS
}

Natalia Govoruskina ${ }^{1}$, Ivan Srejovic ${ }^{2}$, Stefani Bolevich ${ }^{3}$, Sergey Bolevich ${ }^{4}$, Bella Tachieva ${ }^{4}$, Israpil Alisultanovich Omarov ${ }^{5}$, Jovana Jeremic ${ }^{6}$, Katarina Radonjic ${ }^{6}$ and Vladimir Jakovljevic ${ }^{2}$

${ }^{1}$ I.M. Sechenov First Moscow State Medical University, Department of Human Pathophysiology, Moscow, Russian Federation ${ }^{2}$ University of Kragujevac, Faculty of Medical Sciences, Department of Physiology, Kragujevac, Serbia

${ }^{3}$ I.M. Sechenov First Moscow State Medical University, Institute of Molecular Medicine, Moscow, Russian Federation

${ }^{4}$ I.M. Sechenov First Moscow State Medical University, Department of Human Pathology, Laboratory of Navigational Redox Lipidomics, Moscow, Russian Federation

${ }^{5}$ Medical and Health Center of the Ministry of Foreign Affairs of Russia, Moscow, Russian Federation

${ }^{6}$ University of Kragujevac, Faculty of Medical Sciences, Department of Pharmacy, Kragujevac, Serbia

\author{
EFEKTI BLOKADE N-METIL-D-ASPARTATNOG RECEPTORA NA \\ OKSIDACIONI STATUS SRCA TOKOM KONDICIONIRANJA \\ Natalia Govoruskina ${ }^{1}$, Ivan Srejović ${ }^{2}$, Stefani Bolevich ${ }^{3}$, Sergey Bolevich ${ }^{4}$, Bella Tachieva ${ }^{4}$, Israpil Alisultanovich Omarov ${ }^{5}$, Jovana Jeremić ${ }^{6}$, \\ Katarina Radonjić ${ }^{6}$ i Vladimir Jakovljević ${ }^{2}$ \\ ${ }^{1}$ Prvi moskovski državni medicinski univerzitet I.M. Sechenov, Katedra za patofiziologiju, Moskva, Ruska Federacija \\ ${ }^{2}$ Univerzitet u Kragujevcu, Fakultet medicinskih nauka, Katedra za fiziologiju, Kragujevac, Srbija \\ Prvi moskovski državni medicinski univerzitet I.M. Sechenov, Institut za molekulsku medicinu, Moskva, Ruska Federacija \\ ${ }^{4}$ Prvi moskovski državni medicinski univerzitet I.M. Sechenov, Katedra za humanu patologiju, Laboratorija za navigacijsku redoks lipidomiku, Moskva, \\ Ruska Federacija \\ ${ }^{5}$ Medicinski i zdravstveni centar Ministarstva spoljnih poslova Rusije, Moskva, Ruska Federacija \\ ${ }^{6}$ Univerzitet u Kragujevcu, Fakultet medicinskih nauka, Katedra za farmaciju, Kragujevac, Srbija
}

Received/Primljen: 20.12.2019.

Accepted/Prihvaćen: 30.12.2019.

\section{ABSTRACT}

$N$-methyl-D-aspartate receptor (NMDAR) belongs to ionotropic glutamate receptor family. The most prominent roles of the NMDAR are related to the physiological and pathophysiological processes of the central nervous system (CNS). The link between NMDAR and cardiovascular pathology came into focus due to detrimental effects of homocysteine on the cardiovascular system. Regarding the fact that NMDAR affects $\mathrm{Ca}^{2+}$ homeostasis in cells, one of the main mechanisms which mediate adverse effects of glutamate dyshomeostasis and abnormal NMDAR activity is oxidative stress. Both in ischemia and during reperfusion, there are imbalance in $\mathrm{Ca}^{2+}$ and production of reactive species, which remains one of the basic mechanisms underlining the overall cardiomyocyte death due to myocardial infarction. The aim of this study was to assess the effects of blockade of NMDAR in heart using $M K-801$, in preconditioning and postconditioning fashion and to compare the values of oxidative stress biomarkers. We used Langendorff technique of isolated heart. In the control group, all isolated rat hearts were subjected to global ischemia after stabilization period (perfusion of the whole heart with Krebs-Henseleit solution was stopped) for 20 minutes, followed by 30 minutes of reperfusion. In the preconditioning group, after stabilization period, hearts were perfused with MK-801 for 5 minutes, before global ischemia of 20 minutes which was followed by 30 minutes reperfusion. In the postconditioning group, hearts were perfused with MK-801 during the first 3 minutes of reperfusion. Results of this study showed antioxidative effects of NMDAR inhibition in pre-and postconditioning of the isolated rat heart.

Keywords: N-methyl-D-aspartate receptor, MK-801, preconditioning, postconditioning, isolated rat heart

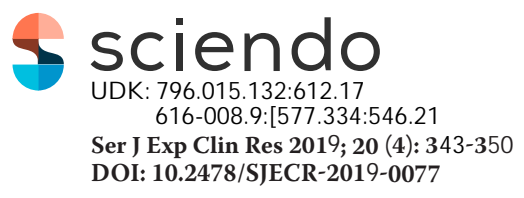

\section{SAŽETAK}

$N$-metil-D-aspartatni receptor (NMDAR) pripada grupi jonotropnih glutamatnih receptora. Najznačajnije funkcije NMDAR se odnose na fiziološke i patofiziološke procese u centralnom nervnom sistemu (CNS). Veza između NMDAR i patoloških procesa kardiovaskularnog sistema je došla u žižu naučnog interesovanja tokom ispitivanja štetnih efekata homocisteina na kardiovaskularni sistem. Imajuci $u$ vidu činjenicu da aktivacija NMDAR remeti homeostazu $\mathrm{Ca}^{2+}$ u ćeliji, jedan od osnovnih mehanizama uključen $u$ ispoljavanje poremećaja glutamatne ravnoteže i patološke aktivnosti NMDAR je oksidacioni stres. Kako tokom ishemije, tako $i$ u reperfuziji, postoji poremećaj ravnoteže $\mathrm{Ca}^{2+}$ i povećana produkcija reaktivnih vrsta, što predstavlja jedan od osnovnih mehanizama koji posreduju u izumiranju kardiomiocita tokom infarkta. Cilj ovog istraživanja je ispitivanje efekata blokade NMDAR upotrebom MK-801 tokom prekondicioniranja i postkondicioniranja i poređenje vrednosti biomarkera oksidacionog stresa. Korišćena je Langendorfova tehnika izolovanog srca. U kontrolnoj grupi sva srca su povrgnuta globalnoj ishemiji odmah nakon perioda stabilizacije (prekinuta je perfuzija čitavog srca Kreps-Henselejtovim rastvorom) u trajanju od 20 minuta, nakon čega je usledila reperfuzija u trajanju od 30 minuta. U grupi sa prekondicioniranjem, nakon stabilizacije aplikovan je MK-801 tokom 5 minuta u koncentraciji od $30 \mu \mathrm{mol} / \mathrm{L}$, nakon čega je sledila globalna ishemija tokom 20 minuta, pa reperfuzija 30 minuta. U grupi sa postkondicioniranjem MK-801 je primenjen tokom prva tri minuta reperfuzije. Rezultati istraživanja ukazuju na antioskidacioni efekat inhibicije NMDAR tokom prekondicioniranja i postkondicioniranja izolovanog srca pacova.

Ključne reči: N-metil-D-aspartatni receptori, MK-801, prekondicioniranje, postkondicioniranje, izolovano srce pacova

Corresponding author: Dr. Ivan M. Srejovic, MD, PhD
Department of Physiology Faculty of Medical Sciences, University of Kragujevac Phone: +381 34342944 Fax: +38134 306800/ext 112 E-mail: ivan srejovic@hotmail.com 


\section{INTRODUCTION}

NMDAR belongs to ionotropic glutamate receptor family, together with AMPA, kainite and delta receptors (1). Structurally, NMDAR is a protein complex composed of four subunits (tetramer) which assembles forming a cation channel. There are three types of NMDAR subunits: GluN1 (binds glycine), GluN2 (binds glutamate) and GluN3 (binds glycine) (2, 3). Functional NMDARs are most often composed of two GluN1 and two GluN2 subunits, and based on this fact the necessity arises for the action of both glycine and glutamate, as co-agonists, for the activation of NMDAR, unlike other members of this receptor family which require only glutamate. Furthermore, in contrast to other ionotropic glutamate receptors, activation of NMDAR enables influx of a considerable amount of $\mathrm{Ca} 2+$ which triggers subsequent $\mathrm{Ca} 2+$-mediated intracellular cascades $(4,5)$. Another particularity of NMDAR is voltage-dependent block by $\mathrm{Mg} 2+$, which makes these receptors both ligand-dependent and voltage-dependent (3).

The most prominent roles of the NMDAR are related to the physiological and pathophysiological processes of the CNS, including synaptic plasticity during development, learning and memory, while impairment of their function are most often related to Huntington's, Alzheimer's or Parkinson's disease (6-8). Over the past decade or so, scientific interest in the roles of NMDAR outside the CNS has grown, and it has been shown that NMDAR takes part in a large number of processes in various non-neuronal tissues (9). Given the fact that NMDAR is Ca2+ channel, it was of great interest to estimate its presence and function in the heart, an organ whose function is strictly dependent on equilibrium in intracellular $\mathrm{Ca} 2+$ homeostasis (10-12). The link between NMDAR and cardiovascular pathology came into focus due to detrimental effects of homocysteine (Hcy) on the cardiovascular system and its underlying mechanisms (13). Actually, it is proposed that Hcy induces overactivation, as well as overexpression, of NMDARs in cardiovascular tissues during hyperhomocysteinemia (HHcy).

Regarding the fact that NMDAR affect $\mathrm{Ca} 2+$ homeostasis in cells, one of the main mechanisms which mediate adverse effects of glutamate dyshomeostasis and abnormal NMDAR activity is oxidative stress $(14,15)$. Namely, overactivation of NMDAR may induce the increase of intracellular $\mathrm{Ca} 2+$ level leading to increased production of prooxidants and shifting redox state of the cell toward oxidative stress and damage. Most of the effects regarding the role of NMDAR in affection of oxidation-reduction processes are described due to nerve tissue and related disorders (16). Furthermore, it was also shown that NMDAR activation has an impact on redox homeostasis in cardiomyocytes and cardiac tissue $(16,17)$.

Despite all the efforts of modern medicine, myocardial infarction remains one of the leading causes of death today. More than 30 years ago, the phenomenon of ischemic preconditioning (IPC) was first described, and since then tremendous scientific efforts have been made to examine new possibilities for myocardial preservation (18). Namely, both in ischemia and during reperfusion there are imbalance in $\mathrm{Ca} 2+$ and production of reactive species, which remains one of the basic mechanisms underlining the overall cardiomyocyte death (19). Besides ischemic preconditioning, many other conditioning maneuvers have been developed over the years that aim to prepare the myocardium in the best possible manner for the onset of ischemia or to reduce damage after ischemia and during reperfusion, including pharmacological possibilities of pre- and postconditioning (20). One of the potential advantages of pharmacological conditioning maneuvers is the ability to act on a large number of molecular targets.

\section{THE AIM OF THE PAPER}

Bearing in mind all the facts, the aim of this study was to assess the effects of blockade of NMDAR in the heart using MK-801, in preconditioning and postconditioning fashion and to compare the values of oxidative stress biomarkers using Langendorff technique of isolated rat heart.

\section{MATERIAL AND METHODS}

\section{Isolated heart preparation according to Langendorff}

Hearts of male Wistar Albino rats were used in this study (10 in each experimental group). All animals were 8 week old, 200 \pm 30 g body weight, obtained from Military Medical Academy, Belgrade, Serbia. After intraperitoneally applied combination of ketamine $(10 \mathrm{mg} / \mathrm{kg})$ and xylazine $(5 \mathrm{mg} / \mathrm{kg})$, rats were sacrificed by cervical dislocation (Schedule 1 of the Animals/Scientific Procedures, Act 1986, UK). Sacrifice was followed by urgent thoracotomy and harvesting of the heart. After a quick removal of the excess of tissue, the hearts were attached to Langendorff apparatus by aorta cannulation. Immediately after aorta cannulation, the hearts were retrogradely perfused under a constant perfusion pressure (CPP) of $70 \mathrm{cmH}_{2} \mathrm{O}$ with complex Krebs-Henseleit solution $(\mathrm{NaCl}$ $118, \mathrm{KCl} 4.7, \mathrm{CaCl}_{2} \cdot 2 \mathrm{H}_{2} \mathrm{O} 2.5, \mathrm{MgSO}_{4} \cdot 7 \mathrm{H}_{2} \mathrm{O} 1.7, \mathrm{NaHCO}_{3}$ $25, \mathrm{KH}_{2} \mathrm{PO}_{4} 1.2$, glucose 11 , pyruvate 2, equilibrated with 95 $\% \mathrm{O}_{2}$ plus $5 \% \mathrm{CO}_{2}$ and warmed to $37^{\circ} \mathrm{C}(\mathrm{pH} 7.4)$ ).

\section{Experimental protocol}

The hearts from all experimental groups underwent 20minute stabilization period. During this period, each of the hearts was subjected to a short-term occlusion (20 s) followed by simultaneous bolus injections of $5 \mathrm{mmol} / \mathrm{l}$ adenosine $(60 \mu \mathrm{l}$ at a flow of $10 \mathrm{ml} / \mathrm{min}$ to elicit maximal coronary flow) to test coronary vascular reactivity. If coronary flow (CF) did not increase by $100 \%$ compared to control values, the hearts were discarded. Coronary flow was determined flowmetrically. When the CF was stabilized (three measurements of the same value repeated), the samples of coronary effluent were collected (control value) and the experimental protocol was initiated. In the control group (CG), all isolated rat hearts were subjected to global ischemia after stabilization period (perfusion of the whole heart with Krebs-Henseleit solution was stopped) for 20 minutes, followed by 30 minutes 
of reperfusion. In the preconditioning group (PreC), after stabilization period, the hearts were perfused with MK-801 (30 $\mu \mathrm{mol} / \mathrm{L}$ ) for 5 minutes, before global ischemia of 20 minutes which was followed by 30 minutes reperfusion. In the postconditioning group (PostC), the hearts were perfused with MK-801 (30 $\mu \mathrm{mol} / \mathrm{L})$ during the first 5 minutes of reperfusion.

The samples of coronary venous effluent were collected during experiments in the same points of interest: after stabilization period (control), after application of MK-801 for PreC group, in the first, third, fifth minute of reperfusion, and further in intervals of 5 minute until the end of the experiment.

All research procedures were carried out in accordance with European Directive for welfare of laboratory animals No 86/609/EEC and principles of Good Laboratory Practice (GLP), approved by Ethical committee of the Faculty of Medical Sciences, University of Kragujevac, Serbia.

\section{Determination of oxidative stress biomarkers}

The following oxidative stress parameters were determined spectrophotometrically (Specord S-600 Analytik Jena) in collected samples of the coronary venous effluent:

1. Index of lipid peroxidation, measured as thiobarbituric acid reactive substances (TBARS)

2. Superoxide anion radical $\left(\mathrm{O}_{2}{ }^{-}\right)$

3. Hydrogen peroxide $\left(\mathrm{H}_{2} \mathrm{O}_{2}\right)$ and

4. Nitrite $\left(\mathrm{NO}_{2}^{-}\right)$.

\section{TBARS determination (index of lipid peroxidation)}

The degree of lipid peroxidation in the coronary venous effluent was estimated by measuring TBARS using 1\% thiobarbituric acid in $0.05 \mathrm{NaOH}$ incubated with the coronary effluent at $100{ }^{\circ} \mathrm{C}$ for $15 \mathrm{~min}$ and measured at $530 \mathrm{~nm}$. KrebsHenseleit solution was used as a blank probe (21).

\section{Nitrite determination}

Nitric oxide decomposes rapidly to form stable metabolite nitrite/nitrate products. Nitrite level $\left(\mathrm{NO}_{2}{ }^{-}\right)$was measured and used as an index of nitric oxide (NO) production using Griess's reagent. A total of $0.5 \mathrm{ml}$ of perfusate was precipitated with $200 \mu \mathrm{l}$ of $30 \%$ sulfosalicylic acid, vortexed for 30 $\mathrm{min}$, and centrifuged at $3000 \mathrm{x} \mathrm{g}$. Equal volumes of the supernatant and Griess's reagent, containing $1 \%$ sulfanilamide in 5\% phosphoric acid $/ 0.1 \%$ naphthalene ethylenediamine-di hydrochloride was added and incubated for $10 \mathrm{~min}$ in the dark and measured at $543 \mathrm{~nm}$. The nitrite levels were calculated using sodium nitrite as the standard (22).

\section{Determination of superoxide anion radical}

The level of superoxide anion radical $\left(\mathrm{O}_{2}^{-}\right)$was measured by nitro blue tetrazolium reaction in TRIS buffer with coronary venous effluent, at $530 \mathrm{~nm}$. Krebs-Henseleit solution was used as a blank probe (23).

\section{Determination of hydrogen peroxide}

A measurement of hydrogen peroxide $\left(\mathrm{H}_{2} \mathrm{O}_{2}\right)$ was based on oxidation of phenol red by hydrogen peroxide, in a reaction catalyzed by horseradish peroxidase (HRPO) (24). 200 $\mu \mathrm{l}$ of perfusate was precipitated with $800 \mathrm{ml}$ of freshly prepared phenol red solution and then $10 \mu \mathrm{l}$ of $(1: 20)$ HRPO (made ex tempore) was added. For blank probe, an adequate volume of Krebs-Henseleit solution was used instead of coronary venous effluent. The level of $\mathrm{H}_{2} \mathrm{O}_{2}$ was measured at $610 \mathrm{~nm}$

\section{Drugs}

All drugs used in this experimental protocol were provided by Sigma-Aldrich.

\section{Statistical analysis}

In CG values of measured biomarkers were compared in three points of interest: the last minute of stabilization (C), the third and the last minute of reperfusion period. In PreC group, we compared the last minute of stabilization (C), the last minute of application of MK-801, and the last minute of reperfusion period. In PostC group, three points of interest were same like in the CG: the last minute of stabilization (C), the third and the last minute of reperfusion. Values are expressed as mean \pm SE. Statistical analysis was performed by ANOVA test. P values lower than 0.05 were considered to be significant.

\section{RESULTS}

The effects of NMDAR conditioning on the values of the Index of lipid peroxidation measured as TBARS

In the CG, values of TBARS were significantly higher in the third and last minute of reperfusion in comparison to the control values. In the PreC group, the application of MK-801 induced significant decrease of TBARS and that decreasing trend continued to the end of the experiment. On the other hand, in the PostC group there were no statistically significant changes in TBARS values (Figure 1A, 1B, 1C).

Figure 1. Values of Index of lipid peroxidation measured as TBARS in group without conditioning (A), preconditioned with MK-801 (B), and postconditioned with MK-801 (C).

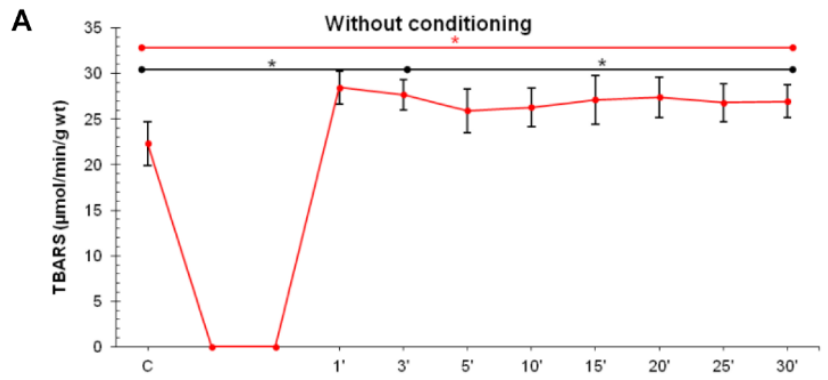


B

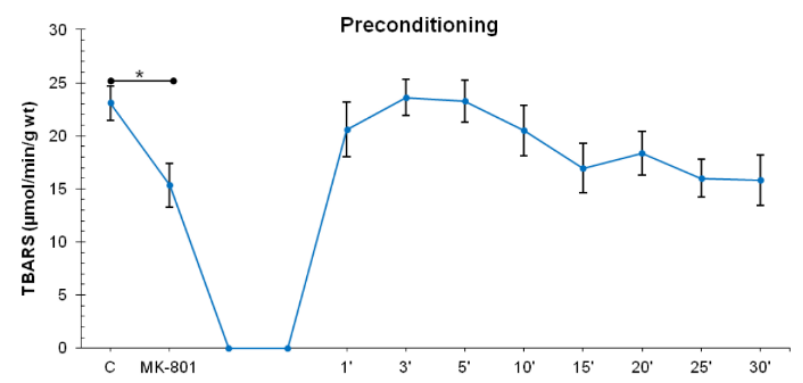

C

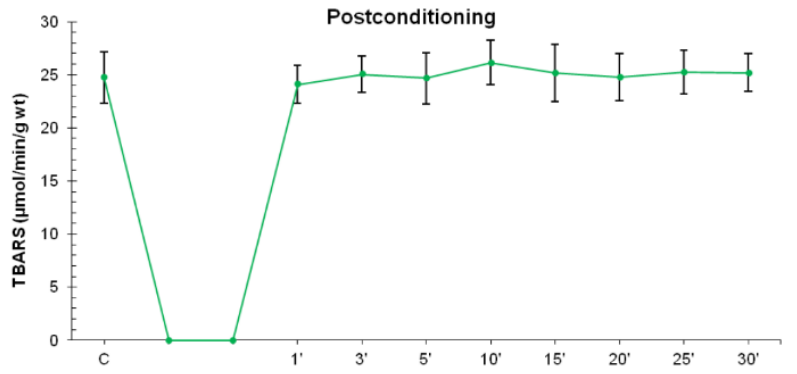

The effects of NMDAR conditioning on the values of the Nitrites

Nitrite $\left(\mathrm{NO}_{2}{ }^{-}\right)$levels did not change significantly in all points of interest in the CG and in the PostC group, while in the $\mathrm{PreC}$ group $\mathrm{NO}_{2}{ }^{-}$values were significantly lower after the administration of MK-801 in comparison to the control values, as well as in the last minute of stabilization (Figure 2A, $2 \mathrm{~B}, 2 \mathrm{C})$.

Figure 2. Values of nitrites in group without conditioning (A), preconditioned with MK-801 (B), and postconditioned with MK-801 (C).

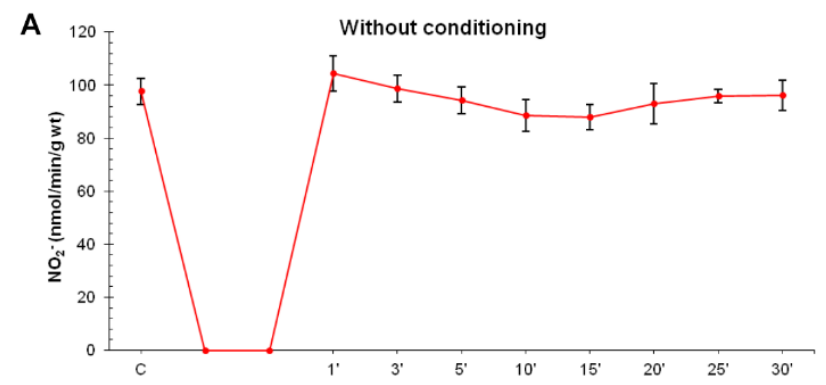

B

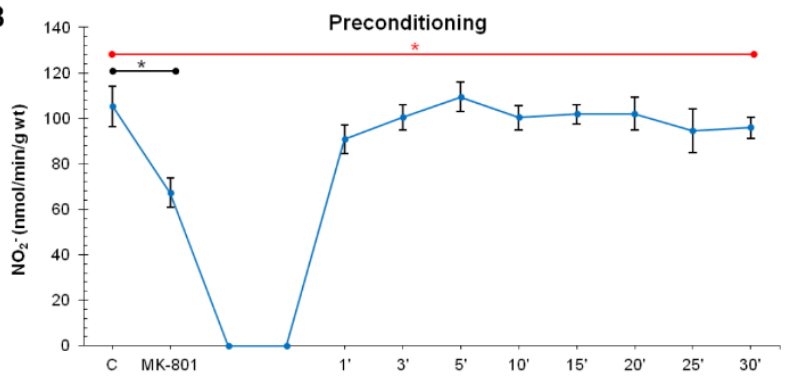

C

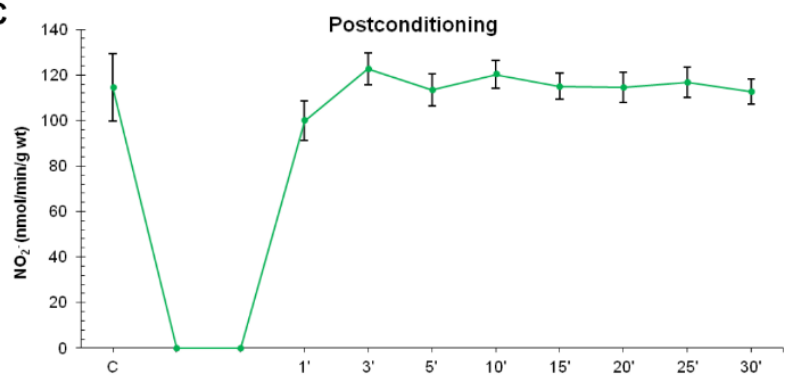

The effects of NMDAR conditioning on the values of the Superoxide anion radical

The values of superoxide anion radical $\left(\mathrm{O}_{2}^{-}\right)$in the CG were significantly increased in the third and last minute of reperfusion compared to the control values, while in the PreC group MK-801 induced significant decrease of $\mathrm{O}_{2}{ }^{-}$levels, but in the postconditioning values were similar to the control values. In the PostC group, there were no statistically significant changes in $\mathrm{O}_{2}^{-}$values (Figure 3A, 3B, 3C).

Figure 3. Values of superoxide anion radical in group without conditioning (A), preconditioned with MK-801 (B), and postconditioned with MK-801 (C).
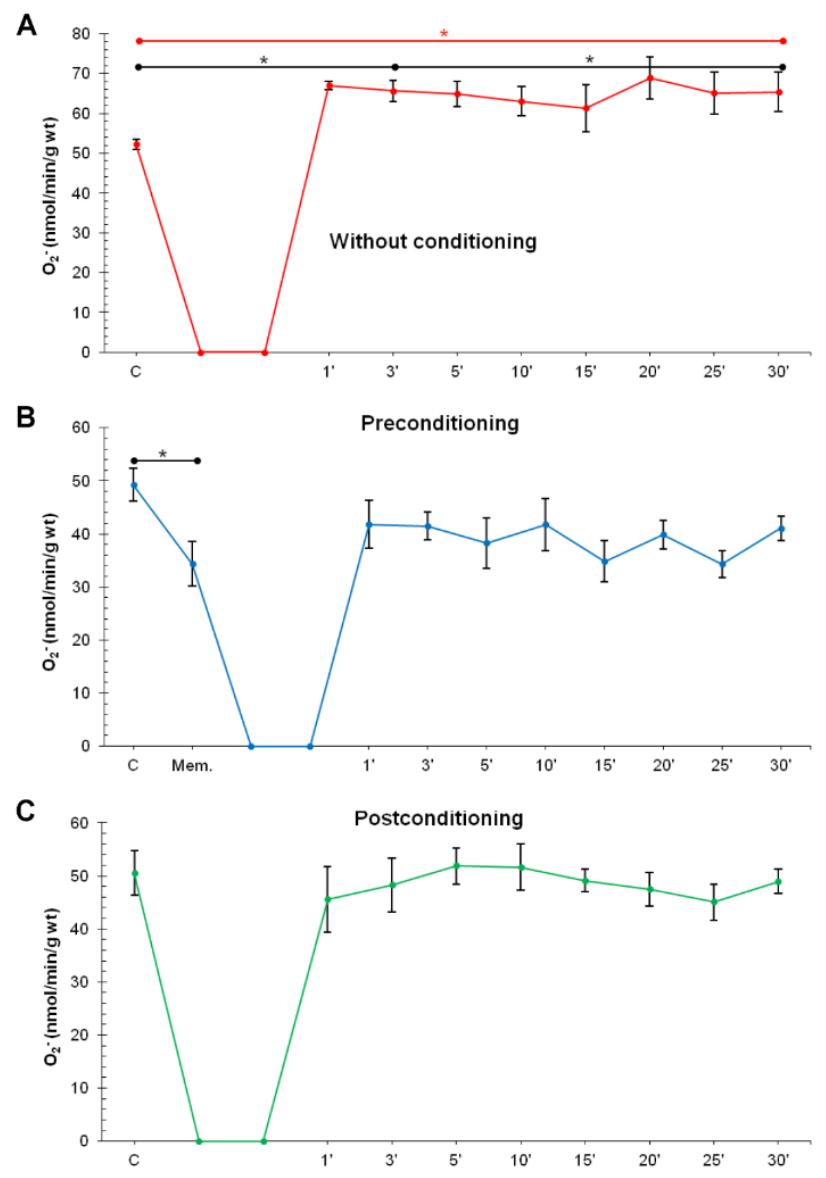
The effects of NMDAR conditioning on the values of the Hydrogen peroxide

Hydrogen peroxide $\left(\mathrm{H}_{2} \mathrm{O}_{2}\right)$ levels in the CG were significantly higher in the last minute of reperfusion compared to the control values. In the PreC group, $\mathrm{H}_{2} \mathrm{O}_{2}$ values were significantly lower after MK-801 application, and also significantly decreased in the last minute of reperfusion in comparison to the control values. Similarly, in the PostC group, $\mathrm{H}_{2} \mathrm{O}_{2}$ levels were significantly lower in the last minute of reperfusion compared to the control values (Figure 4A, 4B, 4C).

Figure 4. Values of hydrogen peroxide in group without conditioning (A), preconditioned with MK-801 (B), and postconditioned with MK-801 (C).

A

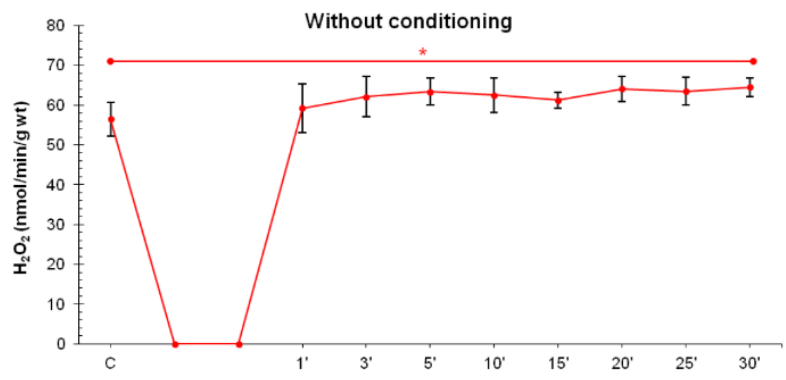

B

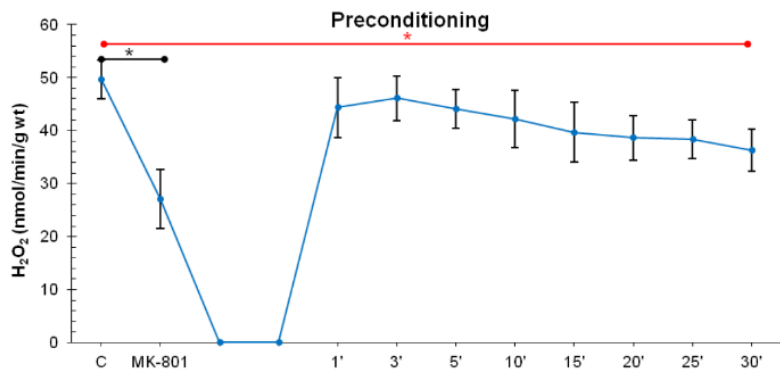

C

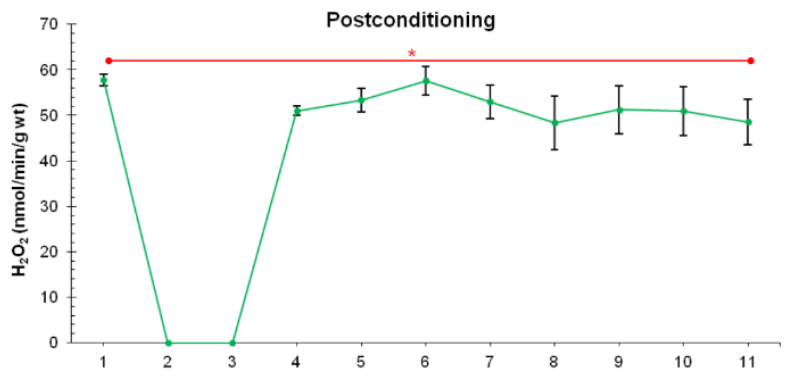

\section{DISCUSSION}

Most researchers dealing with the role of NMDAR in conditioning are related to the nervous system, and there is a lack of data regarding the possible role of these receptors in conditioning models outside the nervous system. Bearing in mind this fact, the aim of this investigation was to assess possible effects of NMDAR blocker, MK-801, applied in preand postconditioning fashion on oxidative stress biomarkers in isolated rat heart model.

It was shown that overactivation of extrasynaptic NMDAR actually has detrimental effect related to excitotoxicity, while activity of synaptic NMDAR, on the contrary, has neuroprotective effect (25). Dickie et al. indicated that the exposure of rat ventral mesencephalic slice cultures to high concentration of NMDA induced pronounced toxicity, while MK-801 abolished these toxic effects of NMDA (26). On the other hand, the use of small doses of NMDA had trophic effects, which also were annulled by MK-801. From these results it can be concluded that activation of NMDAR in nervous tissue may result in protection or damage depending on the localization of NMDAR, as well as on the degree of activation. Several authors indicated the beneficial effects of NMDAR antagonists, primarily MK-801 and memantine, in various models of neuron damage including hypoxia-ischemia and harmful effects of oxygen and glucose deprivation $(27,28)$. Doeppner et al. showed that acamprosate, as indirect NMDAR antagonist, exhibited neuroprotective effects if administered 12 hours before stroke, through inhibition of calpain-mediated pro-injurious signaling cascades (29).

Due to the role of NMDAR in postconditioning Li et al. pointed out that the beneficial effects of brief ischemic postconditioning against amyloid- $\beta$ peptide induced damage in rat hippocampus (30). A brief ischemic postconditioning reduced neuronal loss through upregulation of NMDAR activity and consequent inhibition of MLK3-MKK3/6-P38MAPK signaling pathway, while amantadine as NMDAR antagonist induced canceling out the positive effects of ischemic postconditioning by restoration of MLK3-MKK3/6-P38MAPK.

There is a lack of research dealing with the role of cardiovascular NMDAR in heart conditioning techniques. Gao et al. assessed the activation of the NMDAR in cultures of neonatal rat cardiomyocytes (16). Stimulation with NMDA induced sustained irreversible increase of intracellular content of $\mathrm{Ca}^{2+}$ in cultured cardiomyocytes of neonatal rats, while pretreatment with $30 \mu \mathrm{mol}$ of MK-801 induced partial inhibition of $\mathrm{Ca}^{2+}$ overload. Due to the increased $\mathrm{Ca}^{2+}$ levels, the increase of ROS production regarding NMDA application was also shown, and MK-801 abolished oxidative stress induced by NMDA suggesting the $\mathrm{Ca}^{2+}$ dependent increase of ROS in cardiomyocytes via NMDAR. Findings of McGee and Abdel-Rahman implicate that the increased activity of peripheral NMDAR and consequent increase of ROS production and $\mathrm{Ca}^{2+}$ entrance mediate pressor response (31). Namely, inhibition of phosphoinositide 3-kinase (PI3K)/Akt, protein kinase $\mathrm{C}, \mathrm{Ca}^{2+}$ influx or NADPH oxidase attenuated pressor response induced by activation of peripheral NMDAR, suggesting the role of PI3K/Akt-protein kinase C signaling pathway in changes induced by NMDAR.

In the previous study from our laboratory, MK-801 also induced significant decrease of all oxidative stress biomarkers (32). Experimental protocol of this study implied subsequent administration of DL-Homocysteine and MK801 , as well as their combination, in duration of 5 minutes at constant perfusion pressure. All measured oxidative stress biomarkers, TBARS, $\mathrm{NO}_{2}^{-}, \mathrm{O}_{2}^{-}$and $\mathrm{H}_{2} \mathrm{O}_{2}$, significantly decreased during MK-801 application. On the other hand, 
results of several studies from our research group, regarding the application of NMDAR agonists, showed the increase of oxidative stress parameters $(11,12)$.

Furthermore, there is the other side of the relation between oxidative stress and NMDAR. Betzen et al indicated the fact that oxidative stress increases expression of NMDAR subunits in endothelial cells (33). Using murine cerebrovascular endothelial cells which were exposed to superoxide, peroxynitrite or hydrogen peroxide it was shown that prooxidant environment increased the expression of GluN1 subunit. Increased expression of NMDAR subunits in turn resulted in increased functionality of NMDAR, and further to the increased susceptibility to disruption of blood-brain barrier induced by glutamate.

A considerable number of studies dealing with the role of NMDAR in the cardiovascular system refer to mechanisms mediating the adverse effects of homocysteine. Results of several studies performed by Tyagi et al. pointed out the role of NMDAR in a variety of changes induced by hyperhomocysteinemia (HHcy). Cardiac-specific deletion of NMDAR mitigated decrease in myocyte contraction induced by HHcy (34, 35). Actually, HHcy induced increased production of NO in mitochondria, leading to mitochondrial permeability and further to decline in myocyte mechanical function.

\section{CONCLUSION}

Results of this study undoubtedly showed antioxidative effects of NMDAR inhibition in pre- and postconditioning of the isolated rat heart. Oxidative stress remains one of the key mechanisms mediating cellular and tissue changes due to increased activity of NMDAR. Despite the fact that the results of this study are encouraging, in order to depict a possible role of NMDAR in cardiac protection more precisely and its underlining mechanisms, additional experiments are needed to involve multiple NMDAR agonists and antagonists, which have different effects and act in different ways.

\section{ACKNOWLEDGMENTS}

This project was supported by Grant no. 175043 from the Ministry of Education, Science and Technological Development of the Republic of Serbia, and the Junior Projects 04/2011 and 03/2018, Faculty of Medical Sciences, University of Kragujevac, Serbia.

\section{CONFLICT OF INTERESTS}

None of the authors of the present study has any actual or potential conflicts of interest to disclose, including financial, personal, or other relationships with specific persons or organizations.

\section{REFERENCES}

1. Traynelis SF, Wollmuth LP, McBain CJ, Menniti FS, Vance KM, Ogden KK, Hansen KB, Yuan H, Myers SJ, Dingledine R. Glutamate receptor ion channels: structure, regulation, and function. Pharmacol Rev. 2010;62(3):405-96.

2. Guttmann RP, Sokol S, Baker DL, Simpkins KL, Dong Y, Lynch DR. Proteolysis of the N-methyl-d-aspartate receptor by calpain in situ. J Pharmacol Exp Ther. 2002;302(3):1023-30.

3. Lynch DR, Guttmann RP. NMDA receptor pharmacology: perspectives from molecular biology. Curr Drug Targets. 2001;2(3):215-31.

4. Dingledine R, Borges K, Bowie D, Traynelis SF. The glutamate receptor ion channels. Pharmacol Rev. 1999;51(1):7-61.

5. Cull-Candy S, Brickley S, Farrant M. NMDA receptor subunits: diversity, development and disease. Curr Opin Neurobiol. 2001;11(3):327-35.

6. Hardingham GE. Coupling of the NMDA receptor to neuroprotective and neurodestructive events. Biochem Soc Trans. 2009;37(Pt 6):1147-60.

7. Wang R, Reddy PH. Role of Glutamate and NMDA Receptors in Alzheimer's Disease. J Alzheimers Dis. 2017;57(4):1041-1048.

8. Olivares D, Deshpande VK, Shi Y, Lahiri DK, Greig $\mathrm{NH}$, Rogers JT, Huang X. N-methyl D-aspartate (NMDA) receptor antagonists and memantine treatment for Alzheimer's disease, vascular dementia and Parkinson's disease. Curr Alzheimer Res. 2012;9(6):746-58.

9. Bozic M, Valdivielso JM. The potential of targeting NMDA receptors outside the CNS. Expert Opin Ther Targets. 2015;19(3):399-413.

10. D'Amico M, Di Filippo C, Rossi F, Rossi F. Arrhythmias induced by myocardial ischaemia-reperfusion are sensitive to ionotropic excitatory amino acid receptor antagonists. Eur J Pharmacol. 1999;366(2-3):167-74.

11. Srejovic I, Zivkovic V, Nikolic T, Jeremic N, Stojic I, Jeremic J, Djuric D, Jakovljevic V. Modulation of Nmethyl-d-aspartate receptors in isolated rat heart. Can J Physiol Pharmacol. 2017;95(11):1327-1334.

12. Srejovic I, Jakovljevic V, Zivkovic V, Djuric D. Possible Role of N-Methyl-D-Aspartate Receptors in Physiology and Pathophysiology of Cardiovascular System. Ser J Exp Clin Res 2019; 20(1):3-13.

13. Djuric D, Jakovljevic V, Zivkovic V, Srejovic I. Homocysteine and homocysteine-related compounds: an overview of the roles in the pathology of the cardiovascular and nervous systems. Can J Physiol Pharmacol. 2018;96(10):991-1003.

14. Kamat PK, Rai S, Swarnkar S, Shukla R, Nath C. Mechanism of synapse redox stress in Okadaic acid (ICV) induced memory impairment: Role of NMDA receptor. Neurochem Int. 2014;76:32-41.

15. Hardingham GE, Bading H. Synaptic versus extrasynaptic NMDA receptor signalling: implications for neurodegenerative disorders. Nat Rev Neurosci. 2010;11(10):682-96.

16. Gao X, Xu X, Pang J, Zhang C, Ding JM, Peng X, Liu $\mathrm{Y}$, Cao JM. NMDA receptor activation induces mitochondrial dysfunction, oxidative stress and apoptosis in cultured neonatal rat cardiomyocytes. Physiol Res. 2007;56(5):559-69. 
17. Stojic I, Srejovic I, Zivkovic V, Jeremic N, Djuric M, Stevanovic A, Milanovic T, Djuric D, Jakovljevic V. The effects of verapamil and its combinations with glutamate and glycine on cardiodynamics, coronary flow and oxidative stress in isolated rat heart. J Physiol Biochem. 2017;73(1):141-153.

18. Hausenloy DJ, Barrabes JA, Bøtker HE, Davidson SM, Di Lisa F, Downey J, Engstrom T, Ferdinandy P, Carbrera-Fuentes HA, Heusch G, Ibanez B, Iliodromitis EK, Inserte J, Jennings R, Kalia N, Kharbanda R, Lecour S, Marber M, Miura T, Ovize M, Perez-Pinzon MA, Piper HM, Przyklenk K, Schmidt MR, Redington A, RuizMeana M, Vilahur G, Vinten-Johansen J, Yellon DM, Garcia-Dorado D. Ischaemic conditioning and targeting reperfusion injury: a 30 year voyage of discovery. Basic Res Cardiol. 2016;111(6):70.

19. Hausenloy DJ, Yellon DM. Myocardial ischemia-reperfusion injury: a neglected therapeutic target. J Clin Invest. 2013;123(1):92-100.

20. Hausenloy DJ, Yellon DM. Ischaemic conditioning and reperfusion injury. Nat Rev Cardiol. 2016;13(4):193209.

21. Ohkawa H, Ohishi N, Yagi K (1979) Assay for lipid peroxides in animal tissues by thiobarbituric acid reaction. Anal Biochem 95:351-358.

22. Green LC, Wagner DA, Glogowski J, Skipper PL, Wishnok JS,Tannenbaum SR (1982) Analysis of nitrate, nitrite and [15 N] nitrate in biological fluids. Anal Biochem 126:131-138.

23. Auclair C, Voisin E (1985) Nitroblue tetrazolium reduction. In: Greenvvald RA (ed) Handbook of methods for oxygen radical research. CRC Press, Boca Raton, pp 123-132.

24. Pick E, Keisari Y (1980) A simple colorimetric method for the measurement of hydrogen peroxide produced by cells in culture. J Immunol Methods 38:161-170.

25. Vizi ES, Kisfali M, Lörincz T. Role of nonsynaptic GluN2B-containing NMDA receptors in excitotoxicity: evidence that fluoxetine selectively inhibits these receptors and may have neuroprotective effects. Brain Res Bull. 2013;93:32-8.

26. Dickie BG, Holmes C, Greenfield SA. Neurotoxic and neurotrophic effects of chronic N-methyl-D-aspartate exposure upon mesencephalic dopaminergic neurons in organotypic culture. Neuroscience. 1996;72(3):731-41.
27. Tuttolomondo A, Di Sciacca R, Di Raimondo D, Arnao V, Renda C, Pinto A, Licata G. Neuron protection as a therapeutic target in acute ischemic stroke. Curr Top Med Chem. 2009;9(14):1317-34.

28. Makarewicz D, Sulejczak D, Duszczyk M, Małek M, Słomka M, Lazarewicz JW. Delayed preconditioning with NMDA receptor antagonists in a rat model of perinatal asphyxia. Folia Neuropathol. 2014;52(3):270-84.

29. Doeppner TR, Pehlke JR, Kaltwasser B, Schlechter J, Kilic E, Bähr M, Hermann DM. The indirect NMDAR antagonist acamprosate induces postischemic neurologic recovery associated with sustained neuroprotection and neuroregeneration. J Cereb Blood Flow Metab. 2015;35(12):2089-97.

30. Li H, Luo XB, Xu Y, Hou XY. A Brief Ischemic Postconditioning Protects Against Amyloid- $\beta$ Peptide Neurotoxicity by Downregulating MLK3-MKK3/6P38MAPK Signal in Rat Hippocampus. J Alzheimers Dis. 2019;71(2):671-684.

31. McGee MA, Abdel-Rahman AA. Enhanced vascular PI3K/Akt-NOX signaling underlies the peripheral NMDAR-mediated pressor response in conscious rats. J Cardiovasc Pharmacol. 2014;63(5):395-405.

32. Srejovic I, Jakovljevic V, Zivkovic V, Barudzic N, Radovanovic A, Stanojlovic O, Djuric DM. The effects of the modulation of NMDA receptors by homocysteine thiolactone and dizocilpine on cardiodynamics and oxidative stress in isolated rat heart. Mol Cell Biochem. 2015;401(1-2):97-105.

33. Betzen C, White R, Zehendner CM, Pietrowski E, Bender B, Luhmann HJ, Kuhlmann CR. Oxidative stress upregulates the NMDA receptor on cerebrovascular endothelium. Free Radic Biol Med. 2009;47(8):1212-20.

34. Moshal KS, Kumar M, Tyagi N, Mishra PK, Metreveli N, Rodriguez WE, Tyagi SC. Restoration of contractility in hyperhomocysteinemia by cardiac-specific deletion of NMDA-R1. Am J Physiol Heart Circ Physiol. 2009;296(3):H887-92.

35. Tyagi N, Vacek JC, Givvimani S, Sen U, Tyagi SC. Cardiac specific deletion of $\mathrm{N}$-methyl-d-aspartate receptor 1 ameliorates mtMMP-9 mediated autophagy/mitophagy in hyperhomocysteinemia. J Recept Signal Transduct Res. 2010;30(2):78-87. 